Dochody imigrantów i ich transfery zagraniczne, red. Magdalena Butrymowicz,

Piotr Kroczek, Kraków 2019, s. 77-99 (Biblioteczka Prawa 3).

DoI: http://dx.doi.org/10.15633/9788374387804.04

Małgorzata Ćwiek,

oooo-0002-6375-098X

UNIWERSYTET EKONOMICZNY W KRAKOWIE

Paweł Ulman

oooo-0002-1911-8821.

UNIWERSYTET EKONOMICZNY W KRAKOWIE

\title{
Dochody imigrantów i ich transfery zagraniczne ${ }^{1}$
}

Historia Polski w ostatnich wiekach, jak również ostatnich dziesięcioleciach obfituje w zdarzenia, które sprzyjały lub wymuszały emigrację ludności polskiej do innych krajów. Utrata przez Polskę niepodległości w XVIII wieku i nieudane próby jej odzyskania w wieku XIX doprowadziły do wielkiej emigracji Polaków spowodowanej czynnikami politycznymi. Ruch migracyjny ludności polskiej wynikający z przyczyn ekonomicznych zapoczątkowany został w masowej skali pod koniec XIx i na początku xx wieku, kiedy to w latach od 1870 do 1914 wyemigrowało do Usa ok. 4 mln Polaków². Odzyskanie niepodległości po pierwszej wojnie światowej nie zatrzymało emigracji

1 Publikacja została dofinansowana ze środków przyznanych Wydziałowi Zarządzania Uniwersytetu Ekonomicznego w Krakowie, w ramach dotacji na utrzymanie potencjału badawczego.

2 B. Biedka, Osadnictwo polonijne w ośrodkach miejskich na pótnocno-wschodnim wybrzeżu Stanów Zjednoczonych Ameryki Północnej, [w:] Migracje i społeczeństwo. Zbiór Studiów, red. J. E. Zamojski, Warszawa 1995, s. 83-84. 
z Polski. Jak szacuje H. Janowska, w okresie międzywojennym z Polski wyjechało ok. 2,1 mln osób ${ }^{3}$. Okres powojenny charakteryzował się relatywnie niskim poziomem emigracji. Nasilenie tego zjawiska nastąpiło w okresie lat 8o. xx wieku. Według M. Okólskiego ogólna liczba wyjeżdżających $\mathrm{w}$ tym okresie $\mathrm{z}$ Polski wyniosła ok. 2,2 mln osób ${ }^{4}$. W latach 9o. odnotowano spadek migracji długoterminowych na rzecz krótkookresowych, najczęściej natury ekonomicznej. Szacuje się, że w tym okresie (1990-1999) na pobyt stały wyjechało z Polski 216 tys. osób5. Po przystąpieniu Polski do Unii Europejskiej wzrosły migracje Polaków przede wszystkim do krajów UE. Ruch migracyjny ludności stał się relatywnie łatwy, a głównym celem migrantów było i jest uzyskanie lepszych warunków pracy, poprawy warunków materialnych czy rozwój kariery zawodowej.

Wyniki badania reprezentacyjnego przeprowadzonego w ramach ostatniego spisu powszechnego w Polsce w 2011 roku pokazały, że w momencie spisu przebywało (ponad 3 miesiące) za granicą ponad 2017,5 tys. osób mających stałe miejsce zamieszkania w Polsce. Prawie $78 \%$ z nich było emigrantami długookresowymi (przebywali za granicą 12 miesięcy lub dłużej). Wśród emigrantów większość stanowiły kobiety (53,8\%), częściej emigranci wyjeżdżali z miast (65,9\%) niż ze wsi, nawet jeśli weźmie się pod uwagę, że mieszkańcy miast stanowili w 2011 roku większość ludności ogółem (60,8\%). Głównym kierunkiem emigracji Polaków wśród krajów europejskich była Wielka Brytania, w której odnotowano 612 tys. osób, co stanowiło ponad 30\% wszystkich polskich emigrantów. Polscy emigrowali też do Niemiec (22\%), Irlandii $(6,4 \%)$, Holandii (5,2\%) oraz Włoch (4,6\%). Do Ameryki Północnej i Środkowej

3 H. Janowska, Emigracja zarobkowa z Polski 1918-1939, Warszawa 1981, s. 229.

4 M. Okólski, Migracje zagraniczne w Polsce w latach 1980-1989. Zarys problematyki badawczej, „Studia Demograficzne” (1994) nr 3, s. 25.

5 A. Bobrowska, Migracje Polaków po przystąpieniu do Unii Europejskiej, „Colloquium Wydziału Nauk Humanistycznych i Społecznych” (2013) nr 2, s. 52. 
wyemigrowało 13,3\% ogółu polskich migrantów ${ }^{6}$. Najwięcej emigrantów pochodziło z województwa śląskiego - stanowili oni 11\% wszystkich emigrantów. Następnymi w kolejności województwami, z których najczęściej pochodziły osoby opuszczające Polskę, były województwa małopolskie i dolnośląskie. Z kolei w odniesieniu do liczby mieszkańców najwięcej emigrantów miały województwa: opolskie (ok. 106 osób przebywających za granicą na 1000 mieszkańców województwa), podlaskie (ok. 91 osób) i podkarpackie (ok. 84 osoby) ${ }^{7}$ Najczęstszym powodem wyjazdu za granicę było poszukiwanie i podjęcie pracy. Wśród wszystkich emigrantów blisko $73 \%$ deklarowało pracę jako przyczynę emigracji - częściej byli to mężczyźni niż kobiety. Wynik ten znajduje potwierdzenie w wielkości udziału emigrantów w wieku produkcyjnym. Aż 83\% wszystkich osób przebywających za granicą 3 miesiące lub dłużej było zaliczanych do tej kategorii wieku, co jest zdecydowanie wyższym udziałem niż udział osób w wieku produkcyjnym w ogólnej liczbie mieszkańców Polski .

Na podstawie szacunków liczby mieszkańców Polski przebywających czasowo za granicą, dokonanych przez Gus ${ }^{9}$ można stwierdzić (pomimo przybliżonych wartości), że w kolejnych pospisowych latach liczba emigrantów nie tylko nie zmalała, ale dość wyraźnie wzrosła i w roku 2016 wynosiła 2515 tys. mieszkańców Polski.

W związku z tym, że osoby opuszczające Polskę wywodzą się z gospodarstw domowych, warto zwrócić uwagę na skalę tych gospodarstw, które miały w swoim składzie emigranta. Spis powszechny pokazał,

6 GUs, Migracje zagraniczne ludności. Narodowy spis powszechny ludności i mieszkań 2011, Warszawa 2013, s. 49-50.

7 Gus, Migracje zagraniczne..., dz. cyt., s. 52.

8 GUs, Migracje zagraniczne..., dz. cyt., s. 59.

9 GUs, Informacja o rozmiarach i kierunkach czasowej emigracji $z$ Polski $w$ latach 2004-2016, Notatka informacyjna, http://stat.gov.pl/obszary-tematyczne/ludnosc/ migracje-zagraniczne-ludnosci/informacja-o-rozmiarach-i-kierunkach-emigracji-z-polski-w-latach-20042016,2,10.html (19.04.2018). 
że 1307 tys. (9,6\%) gospodarstw domowych w skali kraju miało w swoim składzie co najmniej jedną osobę przebywającą za granicą powyżej 3 miesięcy. Wśród nich 52,2\% były gospodarstwami, w których nie wszystkie osoby były za granicą ${ }^{10}$. Tak duża skala emigracji, w tym ekonomicznej, wiąże się z pozyskiwaniem dochodów za granicą na rzecz funkcjonowania gospodarstw domowych w Polsce. Dochody te są transferowane do Polski i stanowią często zasadnicze źródło utrzymania rodzin.

Celem artykułu jest określenie głównych kierunków transferów pieniężnych imigrantów w skali światowej, a także określenie skali i znaczenia zagranicznych źródeł dochodów polskich gospodarstw domowych dla ich budżetu oraz sytuacji materialnej.

\section{Dochody z zagranicy}

Przekazy z zagranicy (remittances) są rozumiane jako dochody gospodarstw domowych otrzymywane z zagranicy głównie w wyniku pracy zarobkowej członków tych gospodarstw, którzy przebywają czasowo lub na stałe w innym kraju niż kraj zamieszkania ich gospodarstwa domowego ${ }^{11}$. Przekazy te mogą być przesyłane w formie gotówki, za pomocą transferów pieniężnych, w naturze lub w inny, formalny lub nieformalny, sposób.

Na potrzeby analizy przepływów pieniężnych pomiędzy państwem, z którego przekazywane są środki, a państwem, do którego one prze-

10 GUS, Gospodarstwa domowe i rodziny z osobami przebywajacymi czasowo za granica - w świetle wyników badania reprezentacyjnego przeprowadzonego w ramach NSP 2011, http://stat.gov.pl/obszary-tematyczne/ludnosc/migracje-zagraniczne-ludnosci/gospodarstwa-domowe-i-rodziny-z-migrantami-nsp-2011,12,1.html (dostęp 19.04.2018)

11 IMF, International transactions in remittances: guide for compilers and users, International Monetary Fund, Washington (D.C.) 2009, s. 18 
pływają, używa się terminu „przekazy osobiste” (personal remittances) Składają się na nie: transfery osobiste (personal transfers) i wynagrodzenia (kompensacja) pracowników (compensation of employees). Zgodnie z przewodnikiem po międzynarodowych transakcjach i przekazach, wydanym przez Międzynarodowy Fundusz Walutowy, transfery osobiste (personal transfers) obejmują wszystkie bieżące transfery w gotówce lub naturze między rezydentami i nierezydentami danego państwa, niezależnie od źródła dochodów przesyłającego (niezależnie od tego, czy przesyłający uzyskał dochód z pracy, przedsiębiorczości lub tytułu własności, ze świadczeń społecznych i wszelkich innych rodzajów transferów, lub czy są to udostępnione aktywa) oraz niezależnie od relacji między gospodarstwami domowymi (niezależnie od tego, czy jest lub nie ma relacji pokrewieństwa). Z kolei wynagrodzenia pracowników (compensation of employees) odnoszą się do dochodów z zagranicy pracowników sezonowych lub krótkoterminowych, zatrudnionych w gospodarce, w której nie są rezydentami, oraz gdy są rezydentami zatrudnionymi przez nierezydentów. Wynagrodzenia pracowników składają się z trzech głównych elementów: wynagrodzeń w gotówce, wynagrodzeń w naturze oraz składek na ubezpieczenia społeczne płaconych przez pracodawców ${ }^{12}$.

\section{Kanały transferu dochodów z zagranicy}

Transfery zagraniczne mogą się odbywać za pomocą wielu kanałów w zależności od dostępności usług finansowych w poszczególnych krajach, preferencji przekazujących i otrzymujących oraz otoczenia instytucjonalnego. Centrum im. A. Smitha szacuje, że do Polski zaledwie połowa zarobków emigrantów trafia za pośrednictwem systemu bankowego, co oznacza, że strumień dochodów z pracy za granicą może być

12 IMF, International transactions in remittances.., dz, cyt., s. 19-21. 
Rysunek 1. Kanały transferu dochodów z zagranicy

Emigrant/pracownik krótkoterminowy (nadawca w kraju przyjmującym)

Punkt przekazu dochodu (pośrednik w kraju przyjmującym)

- Bank komercyjny, parabank

- Przedsiębiorstwo finansowe specjalizujące się w przekazach pieniężnych

- Poczta, przedsiębiorstwo przewozowe

- Firma windykacyjna, punkt operatora hawali

- Krewni/przyjaciele

Interfejs transferu

- Infrastruktura komunikacyjna i rozliczeniowa, SWIFT

- Transfery telegraficzne, wiadomości telefoniczne

- Instrukcje zamieszczane w internecie

- Fizyczny transport gotówki i dóbr materialnych

Punkt przekazu dochodu (pośrednik w kraju przyjmującym)

- Bank komercyjny, parabank

- Przedsiębiorstwo finansowe specjalizujące się w przekazach pieniężnych

- Poczta, przedsiębiorstwo przewozowe

- Agent firmy windykacyjnej, agent hawali

- Lokalizacja odbiorcy

Odbiorca/beneficjent/rodzina w kraju macierzystym

Źródło: Opracowanie własne na podstawie IMF (2009), International transactions in remittances: guide for compilers and users, International Monetary Fund, Washington, D.C., s. 7. 
w rzeczywistości nawet dwukrotnie wyższy niż oficjalnie rejestrowany. Dzieje się tak dlatego, że środki pieniężne w postaci gotówki są często przewożone osobiście, przez członków rodzin lub znajomych. Wynika to między innymi $\mathrm{z}$ tego, iż w niektórych krajach osoby bez prawa do pracy lub bez prawa pobytu nie mogą zakładać kont bankowych ${ }^{13}$. Pewne ograniczenia w fizycznym przewozie pieniędzy wprowadza art. 18 Prawa Dewizowego, zgodnie z którym przy kwotach stanowiących równowartość 10 ooo EUR lub więcej istnieje obowiązek zgłoszenia ich służbom celnym. Prawo to ma moc obowiązującą na terenie całej Unii i służy monitorowaniu transakcji finansowych w celu przeciwdziałania procederowi „prania brudnych pieniędzy”"14. Rysunek 1. przedstawia najczęściej stosowane, choć nie wszystkie, kanały przekazów dochodów zagranicznych.

Najprostszą formą transferu pieniędzy jest wysłanie ich listem poleconym za pośrednictwem poczty. Ta forma jest jednak obarczona ryzykiem zaginięcia zawartości przesyłki, wiąże się również z koniecznością długiego oczekiwania na jej odbiór. Poczta oferuje także przekazy zagraniczne. W przypadku Poczty Polskiej przekaz taki jest obciążony prowizją 1\%, a odbiorca otrzymuje pieniądze dopiero po 5-6 dniach ${ }^{15}$. Fizyczny transfer gotówki może być dokonywany za pomocą firm kurierskich lub przewozowych. Pieniądze można także przekazać za pośrednictwem znacznie bezpieczniejszych kanałów: instytucji bankowych bądź firm specjalizujących się w przesyłaniu pieniędzy za granicę.

W ramach instytucji bankowych można wyróżnić kilka sposobów dokonywania transferów z pracy za granicą. Jednym z najwygodniejszych są konta walutowe. W swojej funkcjonalności nie różnią się one

13 R. Poskart, Usługi bankowe związane z transferem w obrocie prywatnym środków pieniężnych z zagranicy do Polski, „Nauki o Finansach” (2013) vol. 14, nr 1, s. 197-198.

14 Ustawa z dnia 27 lipca 2002 r. Prawo dewizowe, Dz. U. 2002 nr 141, poz. 1178.

15 http://blog.kurencja.com/jak-najlepiej-przeslac-przelac-wyslac-pieniadze-za-granice (20.04.2018). 
od standardowych rachunków z tą różnicą, że rozliczane są w jednej lub kilku walutach obcych wybranych przez posiadacza konta. Konta walutowe prowadzone są zazwyczaj bezpłatnie, a bank wydaje do nich kartę rozliczaną w obcej walucie, dzięki czemu przy dokonywaniu transakcji klient nie ponosi kosztów związanych z przewalutowaniem płatności na walutę rodzimą, ponosi natomiast koszty prowizji ${ }^{16}$.

Innym sposobem transferu dochodów jest przekazywanie pieniędzy za pomocą przelewu bankowego. Aby wyrównać różnice cenowe pomiędzy bankami za wykonywanie tych samych usług finansowych, powstał Jednolity Obszar Płatności w Euro, czyli se PA (Single Euro Payments Area), pozwalający na obniżenie kosztów przelewów. Większość banków w krajach UE oraz Europejskiego Obszaru Gospodarczego (Islandii, Norwegii, Szwajcarii i Liechtensteinie) jest objęta systemem SEPA, ponieważ oprócz ujednolicenia taryfikatora opłat daje on możliwość znacznego przyspieszenia księgowania przelewów ${ }^{17}$.

Transfer dochodów z zagranicy może się odbywać także z użyciem karty bankomatowej. Niektóre banki oferują klientom otworzenie dwóch kont (bieżącego i oszczędnościowego). Do tych kont otrzymują oni dwie karty, z których jedną można przesłać członkowi rodziny mieszkającemu w innym kraju, umożliwiając mu tym samym podejmowanie gotówki z dowolnego bankomatu obsługującego dany typ karty. Zaletą tej metody jest to, że odbiorca otrzymuje środki natychmiast i nie musi posiadać konta bankowego, wadą zaś to, że karty tego typu mają dzienny limit kwoty, jaką można podjąć z bankomatu.

Transfer dochodów za granicę może odbywać się także za pośrednictwem serwisów specjalizujących się w transferach pieniężnych. Działają one na zasadzie kantoru internetowego. Dokonanie transferu pieniędzy za pośrednictwem serwisu odbywa się w czterech krokach: założenie

16 R. Poskart, Ustugi bankowe..., dz. cyt., s. 199-20o.

17 R. Poskart, Usługi bankowe..., dz. cyt., s. 200-201. 
konta w serwisie, przelanie określonej kwoty w jednej walucie, wymiana przelanej kwoty na inną walutę i przelanie pieniędzy na konto w wybranym kraju. Platformy, takie jak CurrencyFair, TransferWise czy TransferGo, uważane są za bardzo bezpieczne. Zaletą korzystania z serwisów transferów pieniężnych jest także krótki czas oczekiwania oraz niski koszt (niższy nawet o 90\% w porównaniu z opłatami pobieranymi przy przelewach walutowych przez banki ${ }^{18}$.

Omawiając międzynarodowe kanały transferu pieniędzy nie sposób pominąć hawali. Jest to system szybkich transferów pieniężnych oparty na transferze zadłużenia między pośrednikami w hawali, czyli hawaladarami. Hawala jest definiowana jako transfer pieniędzy bez jego ruchu ${ }^{19}$. Hawala rozwinęła się w Indiach i jest popularna szczególnie w kręgach islamskich. W praktyce osoba pragnąca przekazać pieniądze swojej rodzinie przekazuje hawaladarowi określoną sumę pieniędzy z poleceniem wypłaty rodzinie w konkretnym miejscu i czasie. Hawaladar ustala hasło niezbędne do sfinalizowania transakcji. Osoba przekazująca pieniądze telefonicznie informuje rodzinę o warunkach odbioru pieniędzy. W tym samym czasie pośrednik zleca innemu pośrednikowi w mieście, do którego mają być transferowane pieniądze, wypłatę równowartości transferowanej kwoty po ustalonym kursie. Pośrednicy zapisują swoje długi i należności wobec innych pośredników i rozliczają się między sobą .

\section{Transfery dochodów zagranicznych na świecie}

W pracach podejmujących problem przekazów z zagranicy często rozpatruje się je w kontekście powodów, które skłoniły osoby do po-

18 http://blog.kurencja.com/jak-najlepiej-przeslac-przelac-wyslac-pieniadze-za-granice (20.04.2018).

19 P. M. Jost, The Hawala Alternative Remittance System and its Role in Money Laundering, https://www.treasury.gov/resource-center/terrorist-illicit-finance/Documents/Fincen-Hawala-rpt.pdf (20.04.2018). 
zyskiwania dochodów z zagranicy na rzecz swojego gospodarstwa domowego. Jak zauważają Amuedo-Dorantes i $\mathrm{Pozo}^{20}$, w wielu państwach rozwijających się zmienność i niepewność dochodów jest kluczową przyczyną poszukiwania takich ich źródeł, które pozwolą ustabilizować sytuację ekonomiczną gospodarstwa domowego i podnieść poziom życia w szczególności w przypadku gospodarstw doświadczających ubóstwa. Również Dean Yang i HwaJung $\mathrm{Choi}^{21}$ pokazali, że przekazy z zagranicy są odpowiedzią na jednorazowe szoki w finansach gospodarstwa domowego, dzięki czemu mogą pomóc w stabilizacji w czasie jego dochodów. Jednak powodów pozyskiwania dochodów z zagranicy jest więcej. Na temat motywacji migrantów do przekazywania dochodów z zagranicy wypowiadają się m.in. Amuedo-Dorantes Pozo ${ }^{22}$, Bauer and Sinning ${ }^{23}$, lub Ilahi i Jafarey ${ }^{24}$. Szeroko na temat motywacji do pozyskiwania dochodów z zagranicy i wpływu takich dochodów na sytuację gospodarstw domowych oraz wzrost gospodarczy można znaleźć w pracy Yang ${ }^{25}$.

Znaczenie dochodów pozyskiwanych z zagranicy jest coraz większe. Jak pokazuje rysunek 2., poziom osobistych transferów wzrastał dynamicznie zwłaszcza od 2000 roku. W Europie jest to czas poszerzania się Unii Europejskiej, a na świecie czas zwiększonej mobilności migracyjnej wynikającej z większych możliwości komunikacyjnych,

20 C. Amuedo-Dorantes, S. Pozo, Remittances and Income Smoothing, „American Economic Review" (2011) nr 101 (3), s. 582.

21 D. Yang, H. Choi, Are Remittances Insurance? Evidence from Rainfall Shocks in the Philippines, „The World Bank Economic Review” (2007), nr 21 (2).

22 C. Amuedo-Dorantes, S. Pozo, Remittances..., art. cyt.

23 T. Bauer, M. Sinning, The Purpose of Remittances: Evidence from Germany, „Jahrbücher für Nationalökonomie und Statistik" (2009) nr 229 (6).

24 N. Ilahi, S. Jafarey, Guestworker migration, remittances and the extended family: evidence from Pakistan, "Journal of Development Economics” (1999) nr 58 (2).

25 D. Yang, Migrant Remittances, „The Journal of Economics Perspectives” (2011) nr 25 (3). 
Rysunek 2. Wielkość dochodów z zagranicy w latach 1970-2014

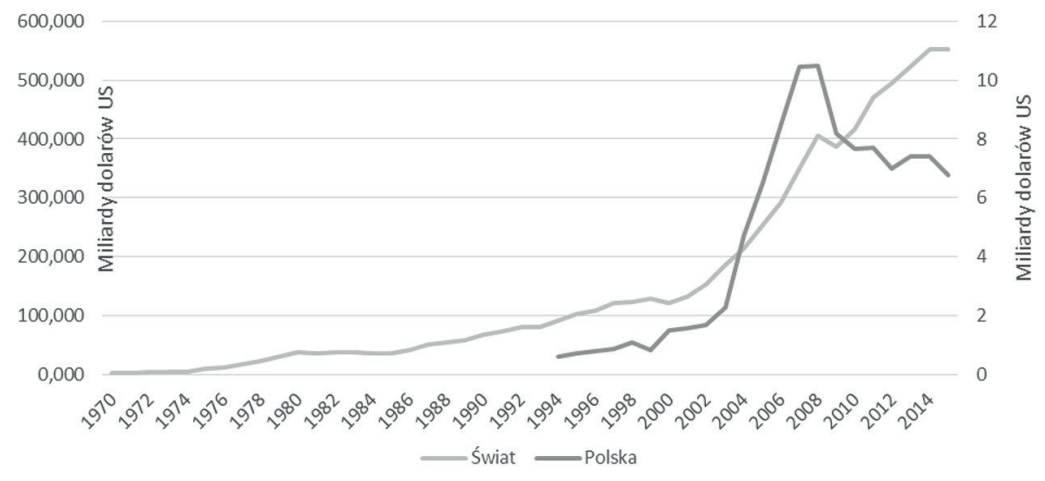

Źródło: opracowanie własne na podstawie The World Bank, Migration and Remittances Data

liberalizacji ograniczeń administracyjnych oraz, niestety wielu konfliktów w różnych częściach świata. W Polsce obserwujemy wyraźny wzrost poziomu przekazów z zagranicy w okresie po wstąpieniu do Unii Europejskiej. Światowy kryzys ekonomiczny końca pierwszej dekady Xxi wieku ograniczył poziom dochodów z zagranicy przesyłanych do Polski. W kilku ostatnich latach zaobserwować można tendencję malejącą poziomu tych dochodów, co może wiązać się zakorzenieniem pobytu dużej części migrantów w danym kraju destynacji migracyjnej. Podjęcie decyzji o stałym pobycie na emigracji wiąże się często $\mathrm{z}$ dołączeniem do osoby, która pierwotnie wyemigrowała jej rodziny, co z kolei naturalnie eliminuje przekazy dochodów z zagranicy do Polski.

Podobne wnioski można wysnuć z rysunku 3., na którym pokazano udział przekazów z zagranicy w relacji do Produktu Krajowego Brutto (Ркв). Szacuje się, że udział ten w skali świata wzrósł w latach 20002014 dwukrotnie (z 0,4\% do o,8\%). W Polsce najwyższy udział dochodów zagranicznych w relacji do РКв został zarejestrowany w 2007 roku i wynosił 2,5\% (tj. sześciokrotnie więcej niż w 2000 roku). Natomiast 
Rysunek 3. Dochody z zagranicy w relacji do РКв w latach 1977-2015

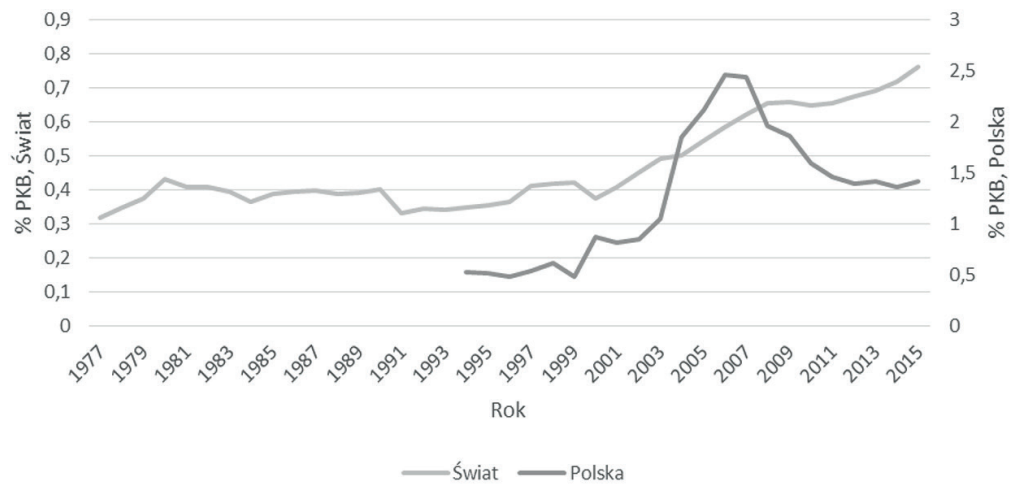

Źródło: opracowanie własne na podstawie The World Bank, Migration and Remittances Data

Tabela 1. Główne kierunki migracji i transferu dochodów na świecie

\begin{tabular}{|c|c|c|c|c|}
\hline \multirow{2}{*}{$\begin{array}{c}\text { Kierunek } \\
\text { przepływu }\end{array}$} & Mln osób & $\begin{array}{c}\text { udział w migracji } \\
\text { ogółem }\end{array}$ & mld USD & $\begin{array}{c}\text { Dochody zagraniczne } \\
\text { zagranicznych } \\
\text { ogółem }\end{array}$ \\
\cline { 2 - 5 } & 93,1 & 38 & 206,7 & 34 \\
\hline $\begin{array}{c}\text { Z południa } \\
\text { na południe }\end{array}$ & 84,3 & 34 & 27,9 & 5 \\
\hline $\begin{array}{c}\text { Z południa } \\
\text { na północ }\end{array}$ & 55,7 & 22 & 143,0 & 24 \\
\hline Z północy na północ & 14,2 & 6 & 223,8 & 37 \\
\hline $\begin{array}{c}\text { Z północy } \\
\text { na południe }\end{array}$ & & 20 & \\
\hline
\end{tabular}

Źródło: J. Staśkiewicz, Migrants' Remittances in Developing Countries, „Trends in the World Economy" (2017) vol. 9, Regionalisation Issues in the Age of Global Shifts, s.159.ć

w 2015 roku w wyniku zmniejszenia transferów dochodów zza granicy ich udział w relacji do РКв wynosił 1,6\%.

Główne kierunki światowych transferów pieniężnych są nierozerwalnie związane z trendami migracyjnymi (por. tabela 1.). Prawie 40\% transferów dochodów zagranicznych odbywa się w kierunku północ - 
Rysunek 4. Kraje otrzymujące największe dochody z zagranicy w latach 2014 roku (w mld USD)

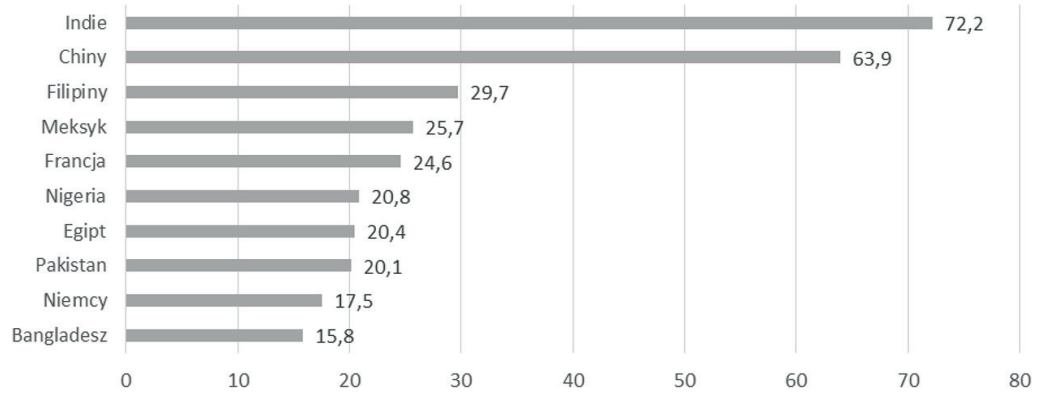

Źródło: World Bank Group, Migration and Remittances. Factbook 2016, $3^{\text {rd }}$ edition, https:// openknowledge.worldbank.org/bitstream/handle/10986/23743/9781464803192.pdf, s. 12.

południe. $\mathrm{Z}$ południa na południe przekazywana jest jedna trzecia transferów pieniężnych, a z południa na północ - jedynie $5 \%{ }^{26}$.

W skali całego świata najwyższy poziom otrzymywanych przekazów odnotowano w 2014 roku w Indiach i Chinach, co nie powinno dziwić z powodu najliczniejszych społeczeństw zamieszkujących w tych państwach, a także znacznych nierówności społecznych. Były to kwoty odpowiednio 72,2 mld usd i 63,9 mld usD (por. rysunek 4.). Do krajów o najwyższym udziale dochodów zagranicznych w PK B należą Tadżykistan (blisko 42\%) i Kirgistan (30,3\%). Ponad 20\% Ркв pochodziło z dochodów zagranicznych w Nepalu, Tongo, Mołdawii, Liberii, na Bermudach, Haiti i Komorach ${ }^{27}$.

Wśród państw, z których są wysyłane przekazy zagraniczne, najwyższy ich poziom odnotowano w USA oraz Arabii Saudyjskiej (por. rysunek 5.), natomiast najwyższy odpływ dochodów względem Ркв miał

26 World Bank Group, Migration and Remittances. Factbook 2016, 3rd edition, https:// openknowledge.worldbank.org/bitstream/handle/10986/23743/9781464803192.pdf, s. 11 (20.10.2018).

27 World Bank Group, Migration and Remittances..., dz. cyt., s. 13. 
Rysunek 5. Kraje transferujące najwięcej dochodów za zagranicę w 2014 r. (w mld USD)

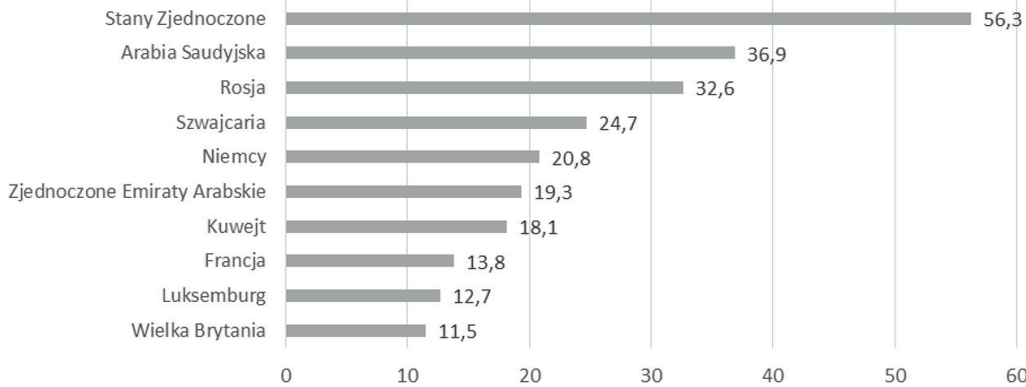

Źródło: World Bank Group, Migration and Remittances. Factbook 2016, $3^{\text {rd }}$ edition, https:// openknowledge.worldbank.org/bitstream/handle/10986/23743/9781464803192.pdf, s. 14 .

Luksemburg (19,6\%). Tylko z Us A do Meksyku zostało przetransferowanych ponad 25 mld USD , a kolejne 16,3 mld USD Z USA do Chin. Szeroką informacje na temat przekazów zagranicznych w skali całego świata można znaleźć w Migration and Remittances. Factbook $2016^{28}$.

Jak pokazuje rysunek 6, w okresie 1990-2015 transfery dochodów zagranicznych do krajów rozwijających się stale rosły. Świadczy to o ich odporności na globalne zawirowania. Inne rodzaje kapitału płynące do rozwijających się gospodarek ostro reagowały na wahania stóp procentowych oraz perspektywy wzrostu w krajach rozwijających się.

\section{Transfery dochodów zagranicznych w Polsce}

Rysunek 7. przedstawia saldo transferów dochodów zagranicznych w Unii Europejskiej. Polska obok takich krajów, jak: Portugalia, Czechy, Węgry Chorwacja, Estonia czy Szwecja, znajduje się w grupie państw o dodatnim saldzie transferów pieniężnych. Oznacza to, że więcej środków napływa do Polski, niż jest wysyłane za granicę. W 2015 roku

28 World Bank Group, Migration and Remittances..., dz. cyt. 
Rysunek 6. Transfery dochodów zagranicznych a inne formy pomocy w krajach rozwijających się (w mld USD)

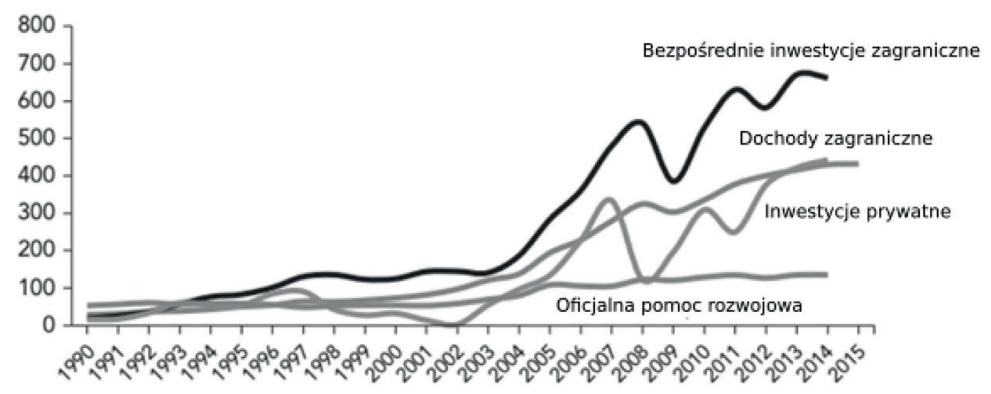

Źródło: The World Bank, Migration and Remittances Data, s. 17.

Rysunek 7. Transfery pieniężne w Unii Europejskiej w 2015 roku

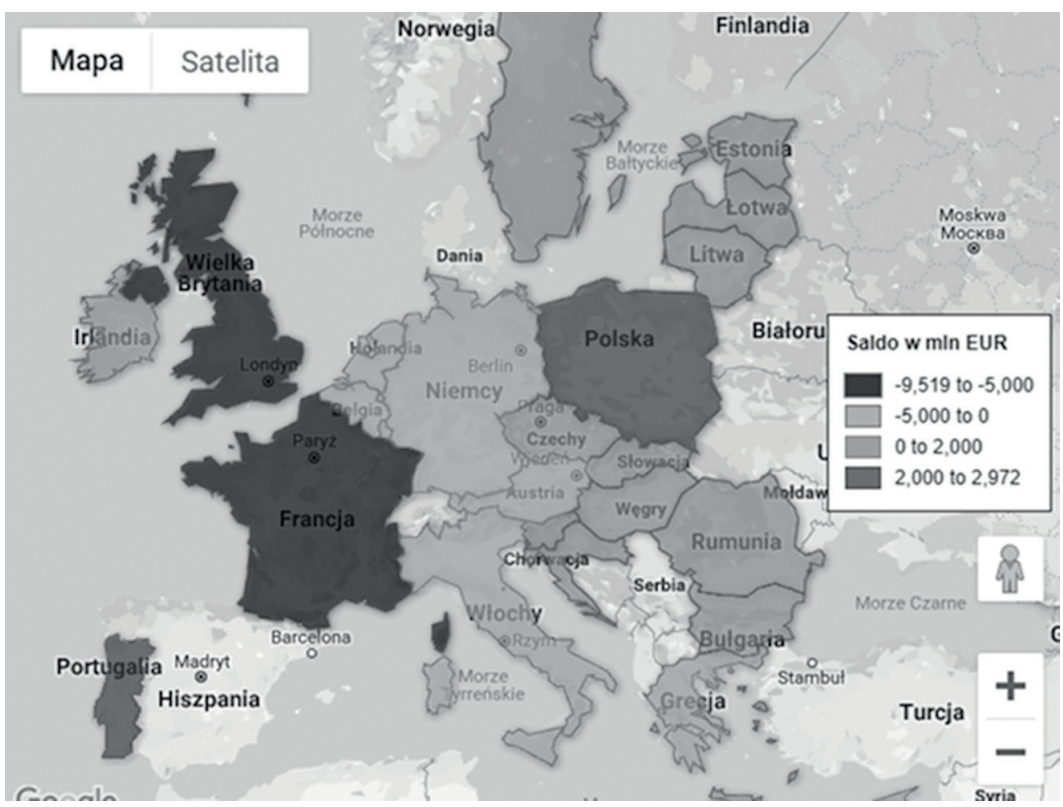

Źródło: http://forsal.pl/artykuly/10o9494,transfery-pieniezne-w-ue-tak-pieniadze-emigrantow-kraza-po-europie-polska-zyskuje-najwiecej.html (20.04.2018). 
nadwyżka transferów pieniężnych osób prywatnych w Polsce była najwyższa w Unii Europejskiej i wynosiła 3 mld euro.

Najwyższą kwotę dochodów z zagranicy przesłano do Polski w 2007 roku (10,5 mld USD). Od tego czasu poziom transferowanych do kraju dochodów stopniowo się zmniejszał, osiągając w 2016 roku poziom 6,7 mld usD (por. rysunek 8.). Do krajów, z których do Polski są transferowane największe środki, należą Niemcy, Wielka Brytania i usA. W 2016 roku imigranci zamieszkujący te kraje przesłali do swoich rodzin odpowiednio $2088 \mathrm{mln}, 1134 \mathrm{mln}$ i $883 \mathrm{mln}$ USD.

Według szacunków NBP w IV kwartale 2016 roku z tytułu pracy Polaków za granicą do kraju trafiło 4,2 mld PLN. Kwota ta była o o,1 mld zł wyższa niż w analogicznym okresie w 2015 roku.

Migranci przebywający za granicą dłużej niż rok przekazali do Polski o o,1 mld zł mniej niż w IV kwartale 2015 roku. O o,2 mld PLN wyższe były za to transfery od pracowników krótkookresowych. O wzroście przekazów od pracowników krótkookresowych zadecydowały w głównej mierze wyższe transfery od Polaków pracujących w Niemczech i Norwegii. Migranci krótkookresowi wyjeżdżają za granicę na kilka tygodni lub miesięcy w celu podjęcia konkretnej pracy. Ponieważ pobyt za granicą ma charakter krótkookresowy, wyjeżdżający nie wiążą się z gospodarką ani społecznością kraju, w którym pracują, a wszystkie zarobione pieniądze, pomniejszone o koszty utrzymania, trafiają do kraju jeszcze w trakcie wyjazdu lub zaraz po jego zakończeniu.

Spadek w transferach od migrantów długookresowych natomiast dotyczył głównie osób zamieszkujących w Wielkiej Brytanii ${ }^{29}$. Liczne badania nad dochodami zagranicznymi pokazują, że wraz ze wzrostem długości trwania migracji maleje skłonność migrantów do transfero-

29 https://www.bankier.pl/wiadomosc/W-IV-kw-wzrost-transferow-od-emigrantow-lecz-nie-tych-z-Wielkiej-Brytanii-7515042.html (19.04.2018). 
Rysunek 8. Poziom dochodów zagranicznych w Polsce w latach 2006-2016 (w mln USD)

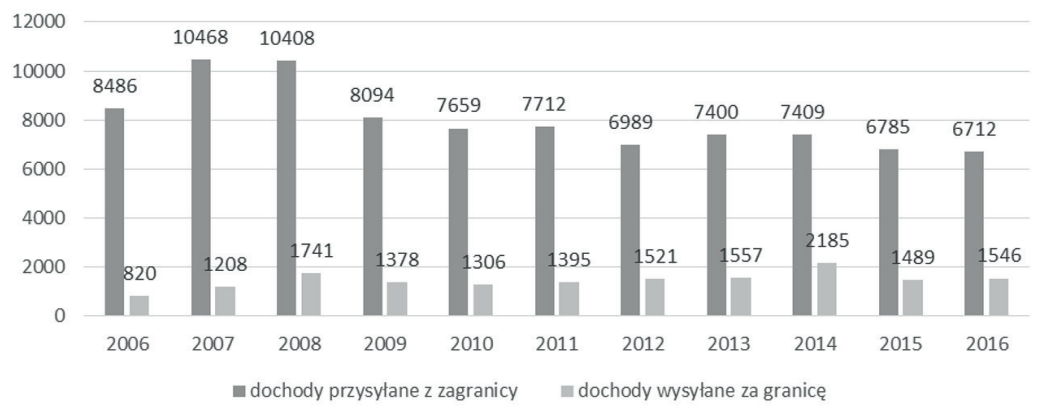

Źródło: World Bank Group, Migration and Remittances. Factbook 2016..., s. 209.

wania środków ${ }^{30}$. Spadek transferów od migrantów długookresowych można wiązać m.in. z rozluźnieniem więzi z członkami rodziny pozostającymi w kraju, poprawą sytuacji materialnej rodziny, ściągnięciem członków rodziny za granicę lub założeniem rodziny na emigracji. Wśród migrantów długookresowych obserwuje się także wzrost wydatków związanych na przykład z zakupem domu lub mieszkania w nowym miejscu oraz aktywniejszym udziałem w życiu społecznym i kulturalnym, następującym wraz z integracją ze społecznością lokalną.

Na względnie stałym poziomie utrzymuje się poziom transferów zagranicznych z Niemiec. Jest to związane z tzw. wahadłowym charakterem emigracji zarobkowej Polaków do tego kraju. Charakteryzuje ich stały charakter pracy i cykliczne powroty do Polski ${ }^{31}$. Stała wysokość transferów z tego kraju wynika również z faktu, że pracę w Niemczech podejmują zwłaszcza osoby posiadające podwójne - polskie i niemieckie - obywatelstwo, które pracowały tam jeszcze przed akcesją

30 I. Chmielewska, Transfery z tytułu pracy Polaków za granica w świetle badań Narodowego Banku Polskiego, Warszawa 2015, s. 23 (Materiały i Studia, 314).

31 R. Poskart, Usługi bankowe..., dz. cyt., s. 197. 
Polski do uE. Warto podkreślić, że dla wielu emigrantów pracujących w Niemczech centrum życia rodzinnego i ekonomicznego znajduje się w Polsce.

Natomiast wielkość dochodów wysyłanych z Polski za granicę systematycznie rośnie, co należy wiązać ze wzrostem imigracji zarobkowej do Polski - głównie obywateli Ukrainy. W latach 2006-2016 wysokość dochodów wysyłanych za granicę wzrosła niemal dwukrotnie: z $820 \mathrm{mln}$ do ponad $1500 \mathrm{mln}$ USD.

\section{Dochody zagraniczne w budżetach polskich gospodarstw domowych}

Udział polskich gospodarstw domowych wykazujących w budżecie dochody z zagranicy wynosi 2,8\%. Wśród gospodarstw domowych $\mathrm{z}$ dochodami z zagranicy prawie $66 \%$ otrzymywało dochody z pracy najemnej stałej za granicą $a^{32}-$ udział tych dochodów w sumie dochodów $\mathrm{z}$ zagranicy to $74,5 \%$.

Dochody z zagranicy otrzymuje najwięcej gospodarstw domowych w województwach: opolskim (8\%), lubuskim $(6,1 \%)$ i podkarpackim (5,9\%). Natomiast najmniejszy udział gospodarstw domowych otrzymujących dochody z zagranicy wykazują województwa o wysokim przeciętnym poziomie zamożności, tj. mazowieckie (1,2\%) i wielkopolskie $(1,3 \%)$.

32 Według metodologii gus na dochody z zagranicy składa się 12 kategorii: dochody z pracy najemnej stałej za granicą, dochody z pracy najemnej dorywczej za granicą, dochody z pracy stałej na własny rachunek za granicą, dochody z pracy dorywczej na własny rachunek za granicą, dochody z wynajmu nieruchomości za granicą, emerytury zagraniczne, renty zagraniczne, renty rodzinne zagraniczne, świadczenia dla bezrobotnych z zagranicy, alimenty od osób prywatnych z zagranicy, pozostałe dary od osób prywatnych dla gospodarstwa z zagranicy oraz pozostałe rodzaje dochodów z zagranicy. 
Tabela 2 Beneficjenci transferów zagranicznych z wybranych krajów.

\begin{tabular}{|c|c|c|c|c|}
\hline Wyszczególnienie & Wielka Brytania & Irlandia & Holandia & Niemcy \\
\hline Rodzice/teściowie & $56 \%$ & $37 \%$ & $38 \%$ & $23 \%$ \\
\hline Na własny rachunek w Polsce & $26 \%$ & $45 \%$ & $36 \%$ & $26 \%$ \\
\hline Żona /mąż (partner/partnerka) & $13 \%$ & $13 \%$ & $20 \%$ & $41 \%$ \\
\hline Dzieci & $11 \%$ & $12 \%$ & $15 \%$ & $19 \%$ \\
\hline Inne & $13 \%$ & $11 \%$ & $13 \%$ & $12 \%$ \\
\hline
\end{tabular}

Źródło: I. Chmielewska, Transfery z tytułu pracy Polaków za granica w świetle badań Narodowego Banku Polskiego, Warszawa 2015, s. 60 (Materiały i Studia, 314).

Dla budżetów gospodarstw domowych istotna jest częstość otrzymywania środków z zagranicy. Według badań NBP ponad połowa (52\%) emigrantów dokonuje przelewów regularnie - raz w miesiącu lub nawet częściej33. Wynika z tego, że środki z zagranicy nie są okazjonalnym zasileniem budżetu gospodarstw domowych członków rodzin emigrantów, ale stanowią jego stały element.

Specyfiką polskiej emigracji zarobkowej jest fakt, że wyjeżdżają głównie ludzie młodzi, nieposiadający jeszcze własnej rodziny, co wpływa na to, do kogo kierowane są transfery z pracy za granicą. Najczęściej beneficjentami remmitances są rodzice lub teściowie emigrantów (38\%). Innymi osobami otrzymującymi dochody z zagranicy są małżonkowie (22\%) i dzieci (14\%). Jedna trzecia emigrantów deklaruje przekazywanie pieniędzy na własny rachunek w Polsce ${ }^{34}$.

Struktura beneficjentów różni się w zależności od kraju, w którym mieszkają osoby przekazujące dochody z zagranicy (por. tabela 2.). Ponad połowa transferów wysyłanych przez osoby zamieszkujące w Wielkiej Brytanii trafia do ich rodziców lub teściów, podczas gdy wśród imigrantów pracujących w Niemczech odsetek ten wynosi jedynie $23 \%$.

33 I. Chmielewska, Transfery z tytułu pracy Polaków..., dz. cyt., s. 45.

34 I. Chmielewska, Transfery z tytułu pracy Polaków..., dz. cyt., s. 60. 
Tabela 3. Dochody z pracy za granicą w budżecie polskich gospodarstw domowych.

\begin{tabular}{|c|c|}
\hline Udział dochodów z pracy za granicą w budżecie & Odsetek gospodarstw domowych \\
\hline Całość & $29,4 \%$ \\
\hline Więcej niż połowa & $46,7 \%$ \\
\hline Połowa & $10,5 \%$ \\
\hline Mniej niż połowa & $11,2 \%$ \\
\hline Nieistotna część & $\mathbf{2 , 2} \%$ \\
\hline
\end{tabular}

Źródło: opracowanie własne na podstawie danych pochodzących z Badania Budżetów Gospodarstw Domowych.

Osoby zamieszkujące w Niemczech najczęściej przekazują pieniądze swoim współmałżonkom lub partnerom - to trzykrotnie częściej niż w przypadku osób zamieszkujących w Wielkiej Brytanii. Jest to związane ze wspomnianym już wahadłowym charakterem emigracji zarobkowej do Niemiec - wiele osób wyjeżdża do pracy sezonowej do Niemiec, ale wyjazdy te traktuje jako tymczasowe, a po zakończeniu pracy wraca do rodziny w Polsce. Znajduje to także swoje odzwierciedlenie w przekazach kierowanych do dzieci.

Jak wynika z tabeli 3., dla większości gospodarstw domowych, które otrzymują dochody z zagranicy, środki te stanowią znaczące źródło utrzymania. Tylko 2,2\% tych gospodarstw domowych uznaje je za nieistotną część budżetu. W przypadku 46,7\% gospodarstw domowych dochody zagraniczne stanowią więcej niż połowę wszystkich dochodów, a w przypadku 29,4\% gospodarstw domowych - całość.

Jak wynika $z$ danych Gus, ponad 90\% gospodarstw domowych otrzymujących transfery pieniężne $\mathrm{z}$ zagranicy zadeklarowało, że otrzymywane dochody mają decydujący lub duży wpływ na zakup dóbr trwałego użytku. 6,8\% gospodarstw domowych określiło wpływ otrzymywanych środków na zakup dóbr trwałego użytku jako mały. Tylko 2,5\% gospodarstw domowych stwierdziło, że otrzymywane dochody zagraniczne nie mają wpływu na dokonywane zakupy. Z przedstawio- 
nych danych wynika, że w gospodarstwach domowych otrzymujących dochody z zagranicy decyzje zakupowe są silnie związane z wysokością transferowanych środków.

Z kolei z danych NBP wynika, że przekazywane środki są zazwyczaj wykorzystywane do sfinansowania więcej niż jednego celu. Zdecydowana większość (ok. 58\%) ankietowanych wskazała bieżące wydatki jako najważniejszy składnik budżetu domowego, na który przeznaczane są dochody z zagranicy. Inne cele to kupno lub remont mieszkania/domu (25\%), oszczędności (17\%), spłata długu (16\%), edukacja dzieci (12\%) oraz specjalistyczne zabiegi zdrowotne $(8 \%)^{35}$.

\section{Zakończenie}

Wstąpienie Polski do Unii Europejskiej oraz otwarcie unijnych rynków pracy dla obywateli naszego kraju spowodowało gwałtowny wzrost emigracji zarobkowej. Zjawisko to skutkuje zwiększeniem dochodów z zagranicy w budżetach polskich gospodarstw domowych. Ze względu na charakter zjawiska, jakim jest transfer dochodów zagranicznych (niewielkie kwoty przekazywane zarówno oficjalnymi, jak i nieoficjalnymi kanałami), nie jest możliwe jego precyzyjne zmierzenie, możliwe jest jedynie dokonywanie szacunków.

Poziom dochodów z zagranicy jest wypadkową procesów migracyjnych oraz wysokości uzyskiwanych dochodów, kosztów utrzymania za granicą oraz więzi z osobami, które pozostały w kraju. W 2016 roku dochody zagraniczne w skali świata wynosiły 585,1 mld dolarów, z czego 442 mld trafiły do krajów rozwijających się. Z uwagi na osobisty charakter przekazów oraz więzi łączące nadawców i odbiorców transfery dochodów zagranicznych stanowią formę pomocy w krajach rozwijających się większą i bardziej stabilną niż oficjalne programy rozwojowe.

35 I. Chmielewska, Transfery z tytułu pracy Polaków..., dz. cyt., s. 61. 
Pomimo zmiany charakteru migracji znacznej części emigrantów z krótkookresowej na długookresową Polska w dalszym ciągu jest krajem zyskującym na przekazach dochodów z zagranicy (więcej środków do Polski napływa, niż odpływa). Dla gospodarstw domowych posiadających dochody z zagranicy stanowią one najczęściej znaczną część ich budżetu i mają istotny wpływ zarówno na poziom bieżącej konsumpcji, jak i zakup przedmiotów trwałego użytkowania.

\section{Streszczenie}

Nasilenie w ostatnich latach procesów migracyjnych jest przyczyną gwałtownego wzrostu transferów dochodów z zagranicy. Zjawisko to jest obserwowane zarówno w Polsce, jak i w skali światowej. Fala emigracji zarobkowej po otwarciu unijnych rynków pracy dla polskich pracowników spowodowała, że wielkość środków napływających do kraju z tytułu pracy za granicą zaczęła mieć istotne znaczenie dla polskiej gospodarki.

Celem artykułu jest charakterystyka głównych kierunków transferów pieniężnych imigrantów w skali światowej, a także określenie skali i znaczenia zagranicznych źródeł dochodów polskich gospodarstw domowych dla ich sytuacji materialnej.

Słowa kluczowe: imigracja, dochody imigrantów, międzynarodowe transfery pieniężne

\section{Summary}

Immigrants' income and international transfers they make

The intensification of migration processes that has taken place in recent years is the cause of a sharp increase in transfers of income from abroad. This phenomenon is observed both in Poland and globally. The wave of economic emigration after the opening of Eu labor markets for Polish employees meant that the amount of funds flowing into the country due to work abroad began to have a significant impact on the Polish economy. 
The aim of the article is to characterize the main directions of monetary transfers of immigrants on a global scale, as well as to determine the scale and importance of remittances of Polish households for their material situation. Keywords: immigration, remittances, international money transfers 
